\title{
Youth Participation in Public Policy at the Local Level New Lessons from Michigan Municipalities
}

What are some strategies for strengthening youth participation in public policy at the local level?

Young people already participate in public policy. There are young people organizing around policy issues, adults involving them in the proceedings of public agencies, and youths and adults collaborating in intergenerational partnerships. There is evidence that initiatives are increasing and will continue in the future.

The National League of Cities, for example, describes approaches to youth service, youth mapping, youth summits, and youth councils in American cities. We worked with Ramona Mullahey and Yve Susskind to offer brief examples of youth participation in community planning, including San Francisco, Seattle, and Salt Lake City. Along with Tanene Allison and Colleen Montoya, we documented the work of the San Francisco Youth Commission. Cindy Carlson and Carmen Sirianni documented the efforts of the Hampton Youth Commission. More recently, Shanetta Martin, Karen Pittman, Thaddeus Ferber, and Ada McMahon documented the work of youth councils and children's cabinets at the state government level.

Still, such efforts are exceptional. Young people do not normally view themselves as a group that can influence policy, adults do not view them as competent citizens, and public officials do not view them as central to their work. Youth participation in pub-

This work is made possible in part by funding from the University of Michigan's Center for Local, State, and Urban Policy and the Michigan Municipal League. Any opinions, findings, conclusions, or recommendations expressed in this material are those of the author(s) and do not necessarily reflect the views of the Center for Local, State, and Urban Policy. In particular the authors want to thank George D. Goodman for his support of the work. The authors also acknowledge Vicky Barnett, Nancy Bates, Steve Brockman, Anissa Eddie, Bryan Farmer, Elizabeth Gerber, Holly Graves, Ellie Gunderson, Shannon Harris, Lynn Heemstra, Dale Iman, Kurt Kimball, Todd Lipa, Michael Maisner, Naomi Milstein, Caitlin Montague, Surabhi Pandit, Bob Parks, Sharon Peters, Kelly Refalo, Robby Saldana, Linda Start, and Bill Waterhouse. lic policy is neither an established field of practice nor a subject of study, although it has promise in both realms. This essay describes efforts to engage young people in public policy at the local level. It draws on a pilot project involving youths and adults in Michigan municipalities, in the hope that more study might contribute to better practice.

\section{Michigan Municipalities}

Michigan has a reputation for youth participation. In one sweep, for example, the Council of Michigan Foundations, with support from the W. K. Kellogg Foundation, established a network of community foundations in every county statewide, each of which established a youth advisory council for involving young people in philanthropy and public work.

With support from the University of Michigan and the Michigan Municipal League, we employed participatory research to involve young people and adult allies in a study of selected municipalities.

We began by forming an advisory committee of local and state representatives with experience and expertise in youth participation, public policy, and municipal affairs. We sought guidance from committee members to formulate criteria for identifying the municipalities, selecting three of them in terms of their level of youth participation, institutional investment, diverse representation, intergenerational involvement, and commitment to project purposes.

Research was conducted in accordance with participatory community-based research principles. Each municipality formed a research committee of youths and adults for documentation and analysis. Site visits were made to collaborate with researchers in reviewing documents, interviewing participants, conducting focus groups, and gathering information. 
We brought together youth and adult representatives of the three municipalities to discuss their research approaches, cross-cutting themes, and lessons learned. They shared the issues and problems they experienced in involving young people and analyzed the factors that facilitate and limit participation at the local level. They participated in preparation of written case studies, and they provided feedback on the accuracy of successive drafts of the report. Here are summaries of the case studies.

Today, the Mayor's Youth Council aims to give "a voice for Grand Rapids youth to city government to plan a better future for when it is in our hands."

\section{Grand Rapids Mayor's Youth Council}

Located in the southwestern part of the state, Grand Rapids is Michigan's second largest city, with a relatively diverse and growing population.

With the formation of an Office of Children, Youth, and Families (OCYF) to strengthen organizational partnerships and community resources for youths and families, the first administrator-a strong youth advocate—argued that young people "should be a presence at city hall." She collaborated with a few high school students to propose an ad-hoc Mayor's Youth Council, and the mayor and city commissioners passed a resolution supporting its creation.

Today, the Mayor's Youth Council aims to give "a voice for Grand Rapids youth to city government to plan a better future for when it is in our hands." Fifteen council members are selected for their potential for future municipal leadership, with special emphasis on representation of racial and ethnic diversity. Council members are sworn in by city commissioners and serve a one-year term.

Council members attend orientation sessions, leadership retreats, and training workshops, such as the annual National League of Cities Congress of Cities, where they participate in issue discussions and interact with other youth council members nationwide.

Council members meet regularly to involve young people in policy formation and municipal gover- nance. During a period of racial tension, for example, they spoke from experience and challenged the mayor to address the issue of racial profiling of young people. Members also serve on municipal committees, participate in strategic planning and budget discussions, hold policy forums, and host an annual conference at which young people present testimony to local, state, and national officials.

The OCYF administrator and a full-time staff person work with council members to manage the process, including transportation to meetings and youth leadership development. The administrator expresses strong commitment to the concept of the council and strengthens its legitimacy inside and outside city hall. She often convinces skeptics about the importance of youth participation and helps young people negotiate their objectives with city leaders.

The Mayor's Youth Council has a growing record of activities and accomplishments. Because of its ad hoc status, however, council advocates struggle to sustain the resources required. Public funding has decreased over time, and most of the present funds come from voluntary contributions and private foundations. The administrator builds ongoing support but is always aware of its status.

Overall, the Mayor's Youth Council enables young people to participate in policy discussions and public affairs at the local level. Some municipal officials express pride in their work, but there is no permanent mechanism to sustain its support over the long haul.

\section{Mayor's Youth Council of Farmington and Farmington Hills}

Farmington and Farmington Hills are middle-class suburbs of Detroit whose elected officials, civic leaders, and school administrators have shown consistent commitment to youth participation.

It was no surprise when the mayor of Farmington Hills sought to build on the after-school programs of the Office of Youth and Family Services. She proposed a Mayor's Youth Council and joined with the mayor of Farmington to institutionalize youth participation through an ordinance to establish a youth council as part of the municipal charter. 
Today theirs is one of the few chartered councils of its kind, for which they receive funding as a line item in the budget and as a recipient of contributions and grants. Council members serve as liaison between young people and municipal government through various activities.

During their bimonthly meetings, they give voice to teenagers and bring youths and government together through regular consultation with the mayors to discuss policy issues, with administrators, and with staff of community agencies. For example, in response to a city ordinance that banned skateboarding, young people discussed the issue with city council and other local officials and then formed an intergenerational committee to design and develop a skateboard park as an alternative solution. Other issues they have addressed are dress code policies in the schools, recycling in city parks, and curfews in the local mall.

They also gather information to assess the needs of young people and use it to plan programs responsive to them. For example, when young people described the lack of adequate teen activities in the community, Youth Council members worked with city officials to create a communitywide teen center.

Staff members prepare young people for involvement in public policy through orientation sessions in which they learn about municipal governance and procedures, meeting facilitation, budget management, events planning, and public speaking.

With their chartered council and line-item budget, Farmington and Farmington Hills do not face some of the issues arising in other municipalities. At the same time, however, they have never tackled an issue that might challenge the power structure or weaken relationships with constituency groups. If this were to happen, and if council members were to use authority as a chartered body to address an issue that put them in opposition to others, it might or might not test the limits of their power.

\section{Southfield Youth Advisory Council}

Southfield is a Detroit suburb whose growth was fueled by "white flight" following World War II and whose population has seen significant sociodemographic change in recent years. An influx of middle-class African Americans, many of them professionals with families moving from city to suburb for secondary education and other services, has transformed the area from predominantly white to predominantly black.

Southfield's civic leaders and school officials have shown commitment to youth participation and represented young people on the school board and other municipal agencies. A community assessment in the 1990s called for further strengthening the involvement of young people, at the same time as the community foundation received funds from the W. K. Kellogg Foundation and the Council of Michigan Foundations to establish the Southfield Youth Advisory Committee (YAC).

YAC members offer community leadership through grantmaking and funding of youth programs and services. They learn to speak out on their beliefs, raise funds for good works, and become active participants in institutions that affect their lives.

Although affiliated with the community foundation, YAC members participate in municipal governance. They serve as representatives on public commissions and municipal agency boards, and they furnish information and consultation on policy issues to municipal officials.

Council members also help to promote partnerships between city departments through the programs they sponsor. For example, the Youth Advisory Council recently worked with city officials to develop a teen center. A youth-adult subcommittee was created to study the issue and make recommendations. They identified support and received commitments for funding. The youths presented their ideas to the Southfield City Council, who voted to approve the proposal; the teen center is moving forward.

YAC members host an annual youth diversity summit, which has become the largest in the area, bringing five hundred to seven hundred students from around the state to discuss institutional and policy issues for strengthening diversity. Young people plan and implement the gathering in cooperation with the city administrator, municipal representatives, and school officials. 
The Southfield Youth Advisory Council is an example of youth participation receiving funding from a community foundation but no formal funding through local government. Despite foundation auspices, however, YAC members have ongoing support from municipal officials, civic leaders, and other adult allies. These allies are instrumental to respecting their role, making their case, and assuring their place at the table.

The Youth Advisory Council offers a distinct approach in which young people represent their interests, set priorities on issues, advocate their positions, and participate in the institutions and decisions that affect their lives. They are not a municipal body and required no public decision for their creation but have become a mechanism for involvement nonetheless.

The Youth Advisory Council offers a distinct approach in which young people represent their interests, set priorities on issues, advocate their positions, and participate in the institutions and decisions that affect their lives.

\section{Observations}

What are some strategies for strengthening youth participation in public policy at the municipal level? A pilot study of this type is necessarily preliminary, but observations are possible nonetheless.

Young people want to participate in public policy at the local level. Given opportunities, they serve in formal and informal roles on youth councils and agency boards. They express positions on issues, speak at meetings, and make recommendations to public officials. They mobilize peers to represent their views and plan programs of their choosing. We believe that the number of youth participants is limitless, an observation in contrast with views of today's youth as withdrawn from community and disengaged from democracy.

Some young people step forward and willingly take leadership roles at the municipal level. They get involved in schools, community organizations, and civic agencies and recognize new leadership opportunities as the next step in their journey. Teachers, mentors, or other adult allies who facilitate their selection also recruit them for their potential. Some receive formal orientation to their roles, whereas others learn through their own experience.

Like adults, these leaders vary in their information and ideas about public policy, their facility with critical thinking and public speaking, and their abilities to represent themselves and their constituents. Some easily express strong positions on issues and produce activities and accomplishments having outcomes in the community and an effect on themselves.

There are adults working with young people to strengthen the scope and quality of their participation. They include teachers offering encouragement, parents driving them from place to place, agency administrators recruiting them for program roles, and elected officials collaborating with them in municipal affairs. Although parents and teachers have special opportunities because young people spend much of their time at home or school, we also observe youths who are growing up in city hall.

Youth participation differs in its institutional structures. In the three Michigan municipalities, we find one youth council with agency advocates but temporary status, another with strong mayoral support and a formal charter in government, and a third affiliated with a community foundation whose young people gain influence through their activities. A permanent charter affords a measure of stability, whereas informal structure can put an initiative in a vulnerable position.

There are forces limiting youth participation at the municipal level. For example, it is difficult to promote participation when community agencies view young people as passive recipients of services rather than as competent citizens, when schools lack quality curricula to prepare them for civic leadership, and when adults treat them as inferior and disregard their potential because of their age. These portrayals do not describe the municipalities in the present study. Nonetheless, the dominant view of young people as being withdrawn or disengaged lowers expectations about youth participation instead of raising them. 
Parents and teachers are often uneven in their orientation to youth participation. Many parents themselves do not participate in public policy and are unable to give something to their children if they do not have it themselves. Many teachers lack curricular models and operate in schools that don't emphasize civic education. It is not surprising that young people sometimes internalize the beliefs of adults and do not see themselves as a group that can create change.

Despite obstacles, there are good examples of municipal agencies that involve youths in public policy, young people who organize around policy issues that concern them, and youths and adults who collaborate in intergenerational policy partnerships. These municipal agencies are not typical, but they do exist, and their efforts offer lessons to learn.

\section{Conclusion}

Young people should participate in public policy at the local level. They should advise the mayor and city council members, participate in public proceedings, and serve on the boards of community agencies. They should identify their own policy issues, plan their own programs, and organize their own action groups. They should view democracy as a process in which they can engage, policy as a way to achieve their goals, and the municipality as a vehicle for their action.

They should participate because it draws on their expertise and improves institutional decisions of municipalities. It increases their civic engagement at a time when the level of engagement is uneven, and strengthens democratic society with its basis in the rule of the people. It prepares them for their roles as citizens, and it enables them to exercise their rights.

The Michigan municipalities described here involve young people in public policy through mayors' offices, municipal agencies, and community foundations. They vary in their origins and objectives, their activities and accomplishments, the roles of youths and adults, and their institutional location and level of support. There is no single approach employed by these municipalities, and this strengthens the potential for work of this type.

These initiatives have an effect on the young people participating, on the institutions and agencies with which they work, and on the community of which they are part. Youth leadership, staff support, charter authority, community context, and external environment surely affect these initiatives. The scope of the present pilot project prevents us from drawing broad generalizations, but it permits us to make preliminary observations about the promise of this work.

There is need for more knowledge of youth participation in public policy at the local level. If there were more knowledge of youth participation in public policy as a subject of study, it would contribute its growth as a field of practice. If this article stimulates more work of this type, its purpose will be fulfilled.

\section{References}

Allison, T. "Whose Turning Point? A Paper on the Experiences of the San Francisco Youth Commission's Work to Influence Legislative Action." Ann Arbor: Michigan Youth and Community Project, 2002.

Carlson, C. "The Hampton Experience as a New Model for Youth Civic Engagement." Journal of Community Practice, 2006, 14(1/2), 89-106.

Checkoway, B., Allison, T., and Montoya, C. "Youth Participation in Public Policy at the Municipal Level." Children and Youth Services Review, 2005, 27, 1149-1162.

Martin, S., Pittman, K., Ferber, T., and McMahon, A. Building Effective Youth Councils: A Practical Guide to Engaging Youth in Policy Making. Washington, D.C.: Forum for Youth Investment, 2007.

Mullaley, R., Susskind, Y., and Checkoway, B. Youth Participation in Community Planning. New York: American Planning Association, 1999.

National League of Cities. Action Tool Kit: Promoting Youth Participation. Washington, D.C.: Institute for Children Youth and Families/National League of Cities, 2002.

Sirianni, C. "Youth Civic Engagement: Systems Change and Culture Change in Hampton, Virginia." CIRCLE, Working Paper \#31, 2005.

Katie Richards-Schuster is an assistant research scientist with the Michigan Youth and Community Program at the University of Michigan's School of Social Work.

Barry Checkoway is a professor of social work and urban planning at the University of Michigan.

For more information, see www.youthandcommunity.org. 